\title{
Probable effect of photoperiod on seasonal variation in the nuclear volume of the adrenal cortex of viscacha (Lagostomus maximus maximus)
}

A.C. Ribes ${ }^{1}$, F. Mohamed ${ }^{1}$,

S. Dominguez ${ }^{1}$, M. Delgado ${ }^{1}$,

L. Scardapane ${ }^{1}$, J. Guzman ${ }^{1}$ and R. Piezzi²
${ }^{1}$ Cátedra de Histología y Embriología, Facultad de Q uímica, Bioquímica y Farmacia, Universidad Nacional de San Luis, San Luis, Argentina

${ }^{2}$ Cátedra de H istología y Embriología, U niversidad Nacional de Cuyo, Mendoza, Argentina

\section{Correspondence \\ A.C. Ribes \\ Cátedra de Histología y Embriología \\ Facultad de Química, Bioquímica \\ y Farmacia \\ Universidad Nacional de San Luis \\ Av. Ejército de los Andes, 950 \\ $2^{\circ}$ Piso \\ 5700 San Luis \\ Argentina \\ Fax: + 54-2652-430-224/422-644 \\ E-mail: aribes@unsl.edu.ar}

Research supported by CO NICET, PIP (N o. 4936), República Argentina and Secretaría de Ciencia y Técnica, Universidad Nacional de San Luis (No. 7303), Argentina.

Received April 30, 1998 Accepted May 11, 1999

\section{Abstract}

The neuroendocrine system regulates several organic functions such as reproduction, metabolism and adaptation to the environment. This system shows seasonal changes linked to the environment. The experimental model used in the present study was Lagostomus maximus maximus (viscacha). The reproduction of males of this species is photoperiod dependent. Twenty-four adult male viscachas were captured in their habitat at different times during one year. The adrenal glands were processed for light microscopy. Serial cuts were stained with hematoxylin-eosin for the morphometric study, and 100 nuclei of each zone of the adrenal cortex were counted per animal. Data were analyzed statistically by ANOVA and the Tukey test. The cells of the glomerulosa zone are arranged in a tube-shaped structure. The fasciculata zone has large cells with central nuclei and clearly visible nucleoli and with a vacuolar cytoplasm. In the reticularis zone there are two of types of cells, one with a nucleus of fine chromatin and a clearly visible nucleolus and the other with nuclear pycnosis. Morphometric analysis showed maximum nuclear volumes during the FebruaryMarch period with values of $133 \pm 7.3 \mu \mathrm{m}^{3}$ for the glomerulosa, 286.4 $\pm 14.72 \mu \mathrm{m}^{3}$ for the fasciculata, and $126.3 \pm 9.49 \mu \mathrm{m}^{3}$ for the reticularis. Minimum nuclear volumes were observed in August with values of $88.24 \pm 9.9 \mu \mathrm{m}^{3}$ for the glomerulosa, $163.7 \pm 7.78 \mu \mathrm{m}^{3}$ for the fasciculata and $64.58 \pm 4.53 \mu \mathrm{m}^{3}$ for the reticularis. The short winter photoperiod to which viscacha is subjected could inhibit the adrenal cortex through a melatonin increase which reduces the nuclear volume as well as the cellular activity.
Key words

- Viscacha (Lagostomus

maximus maximus)

- Adrenal

- Glomerulosa

- Fasciculata

- Reticularis

- Photoperiod

- Morphometry

- Melatonin 


\section{Introduction}

Biological rhythms are essential components of adaptation to environmental challenges and the principal pineal hormone, melatonin, acts as a major synchronizer of endocrine rhythms $(1,2)$. A short photoperiod inhibits the reproduction of several mammals like Microtus agrestis (3), Microtus arvalis (4), Phodopus sungorus (5) and Lagostomus maximus maximus (6). In all

Table 1 - Weight and size of the right and left adrenal gland of viscacha.

Data are reported as means $\pm \mathrm{SEM} . \mathrm{N}=4$.

\begin{tabular}{lcc}
\hline & Right gland & Left gland \\
\hline Weight $(\mathrm{g})$ & $1.2 \pm 0.026$ & $1 \pm 0.027$ \\
Length $(\mathrm{mm})$ & $19 \pm 0.276$ & $22 \pm 0.26$ \\
Width $(\mathrm{mm})$ & $10 \pm 0.25$ & $15 \pm 0.24$ \\
Thickness $(\mathrm{mm})$ & $8.1 \pm 0.276$ & $8.6 \pm 0.305$
\end{tabular}

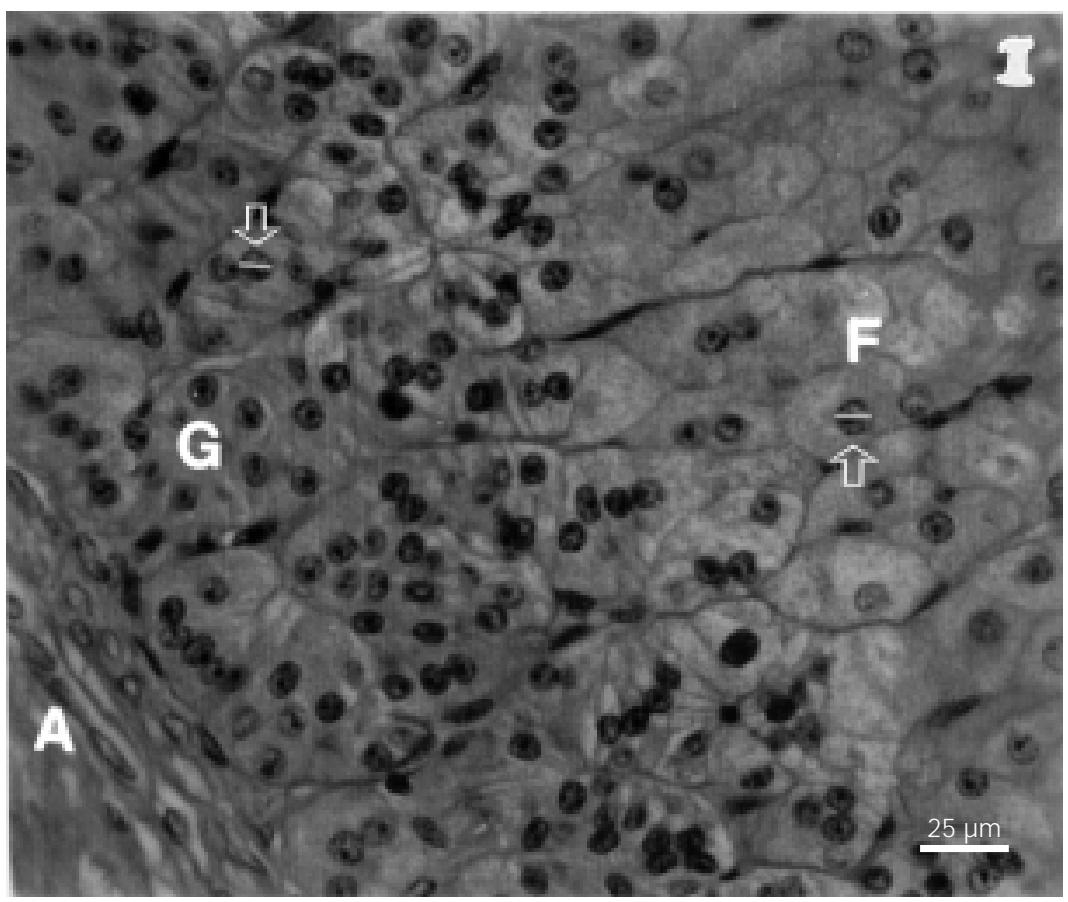

Figure 1 - Glomerulosa and fasciculata regions of a viscacha captured in March (summer). Notice the thick capsule of connective tissue (A). In the glomerulosa zone (G) the cells are clustered in the form of tube-shaped structures. Notice the characteristics of the fine chromatin nuclei and the nuclear diameter of the cells (line indicated by the arrow). The fasciculata region $(F)$ shows large cells with central nuclei. The line shows the nuclear diameter of one of its cells. H-E; 400X. cases, melatonin establishes the connection between the physical nature of light and the biochemical activity in the organism. Reproduction, adaptation to the environment, and diverse metabolic and immunologic processes are controlled by this mechanism.

The relation between the pineal gland and the hypothalamic-pituitary-gonadal axis has been well defined for some species. Moreover, the interrelation between the pineal gland and other glands has been established. In viscacha, the intermediate pituitary is depressed by dark and stimulated by light (7).

It is well known that the hormones released by the adrenal cortex are related to homeostasis and stress mechanisms. The fasciculata and reticularis zones are modulated by the anterior pituitary through ACTH release, which is in turn regulated by hypothalamic factors. It has been reported that melatonin can decrease corticosterone $(8,9)$ and aldosterone (10) levels. This hormone causes selective atrophy within the fasciculata zone in hamsters (11). Moreover, sex steroids could play a crucial role in the regulation of adrenocortical secretion, mainly by acting on the rate-limiting step of steroidogenesis (12).

Our experimental model is the viscacha (Lagostomus maximus maximus), a photoperiodic rodent of night habits. Under natural conditions, the adult male exhibits an annual reproductive cycle (13). In winter, males of this species show minimum pituitary (14) and gonadal activity (15), while the pineal gland shows maximum activity (6), and this is reversed in summer. The objective of the present investigation was to study the morphology of the adrenal cortex of viscacha and correlate it with physiological activities influenced by the natural photoperiod.

\section{Material and Methods}

Twenty-four adult male viscachas 
(Lagostomus maximus maximus) weighing 5-7 kg were captured in their habitat in February, March, May, August, September and November, near San Luis, Argentina ( $33^{\circ} 20^{\prime}$ south latitude and $760 \mathrm{~m}$ altitude) from 1995 to 1997. The animals were anesthetized with Nembutal (pentobarbital) and quickly decapitated. In this region, summer days have $14 \mathrm{~h}$ of light and an average temperature of $25^{\circ} \mathrm{C}$. In winter, the daylight decreases to $10 \mathrm{~h}$ and the average temperature is $10^{\circ} \mathrm{C}$. Average rainfall in this region is $206 \mathrm{~mm}$ in summer and $18 \mathrm{~mm}$ in winter.

Adrenal glands were rapidly removed and fixed in Bouin's fluid, tissue was dehydrated in a graded series of ethanol, cleared in xylene and embedded in paraffin. Serial sections were cut at $5 \mu \mathrm{m}$, mounted on glass slides and stained with hematoxylin and eosin. Stained sections were examined under a light microscope at $1000 \mathrm{X}$ and photographed with a Leitz Wetzlar photomicrographic camera (Germany).

Four adrenal glands (left) were processed per month during February, March, May, August, September and November. The nuclei of 100 cells were examined for each adrenal cortex zone. Thus, 400 nuclei of each adrenal gland were examined during the months mentioned above. Nuclear diameter was measured with an ocular micrometer. The formula utilized to determine the nuclear volume was: Vn: 1/6 p D $\mathrm{D}^{3}(16)$. Data were analyzed statistically by ANOVA and by the Tukey test.

\section{Results}

The right and left adrenal glands of viscachas are located in the kidney cephalic poles and the left adrenal is not adherent as is the case for other rodents. The left gland exhibits an elongated shape while the right one has a pyramidal or conical shape with the vertex towards the cephalic zone. The right gland contacts a large vessel on the side facing the central axis. At this level, histology reveals cortex interruption, and the medulla is in contact with extensive perivascular tissue.

The weight and size of the right and left glands are shown in Table 1. The glands are completely wrapped in a wide capsule of connective tissue. The cortex is yellow and the medulla is red. The cortex-medulla volume ratio is $7-1$.

The cortex is formed by three regions. In the glomerulosa zone, the cells are arranged in a tube-shaped structure. These tubes are separated by connective tissue filaments. The fasciculata region has large cells with a central nucleus (Figures 1 and 2), a clearly visible nucleolus and the cytoplasm is filled with lipid droplets (Figure 3) in March, with lipid content decreasing in August (Figure 4). In the reticularis zone there are two types of cells, one of them presenting a nucleus of fine chromatin and a clearly visible nucleo-



Figure 2 - Glomerulosa and fasciculata regions of a viscacha captured in August (winter). Capsule (A). The cells of the glomerulosa zone (G) at this time of year show pycnotic nuclei (arrow) where a reduction in nuclear diameter (line) can be observed. The fasciculata region (F) shows small cells with nuclei of condensed chromatin (arrow) and a reduced nuclear diameter (line) compared to that observed in March. H-E; 400X. 
lus and a slightly eosinophilic cytoplasm. The other cellular lineage presents nuclear pycnosis and abundant colloidal material. These cells are at the medullar boundary (Figures 5 and 6).

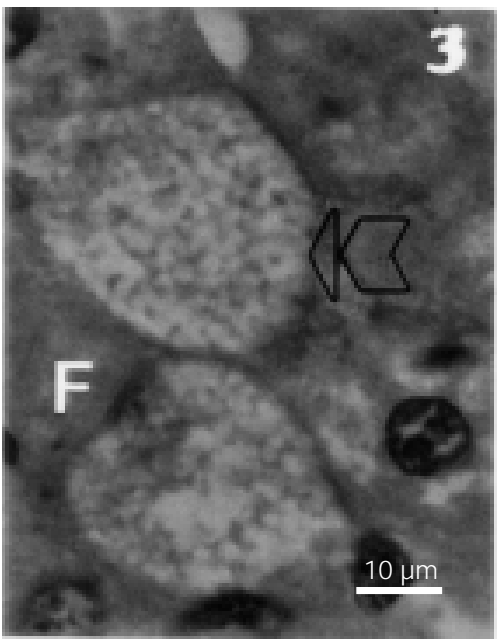

Figure 3 - Fasciculata region (F) of a viscacha captured in March (summer). The cytoplasm of these cells is completely vacuolated (arrow). H-E; 1000X.

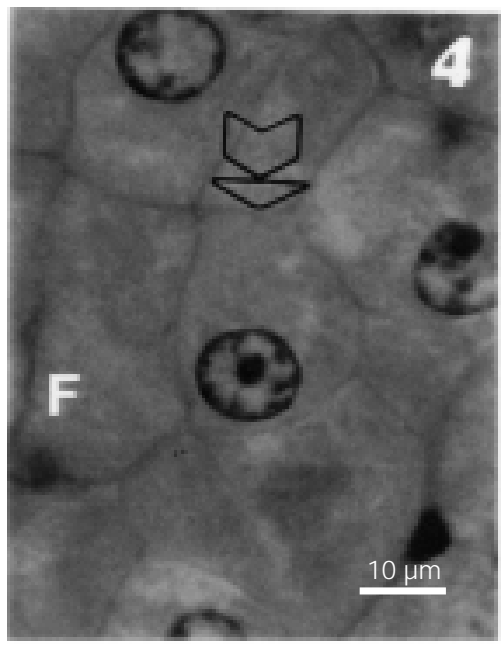

Figure 4 - Fasciculata region (F) of a viscacha captured in August (winter). The cytoplasm shows a pronounced decrease in the content of lipid droplets (arrow) compared to that observed in March. H-E; 1000X.

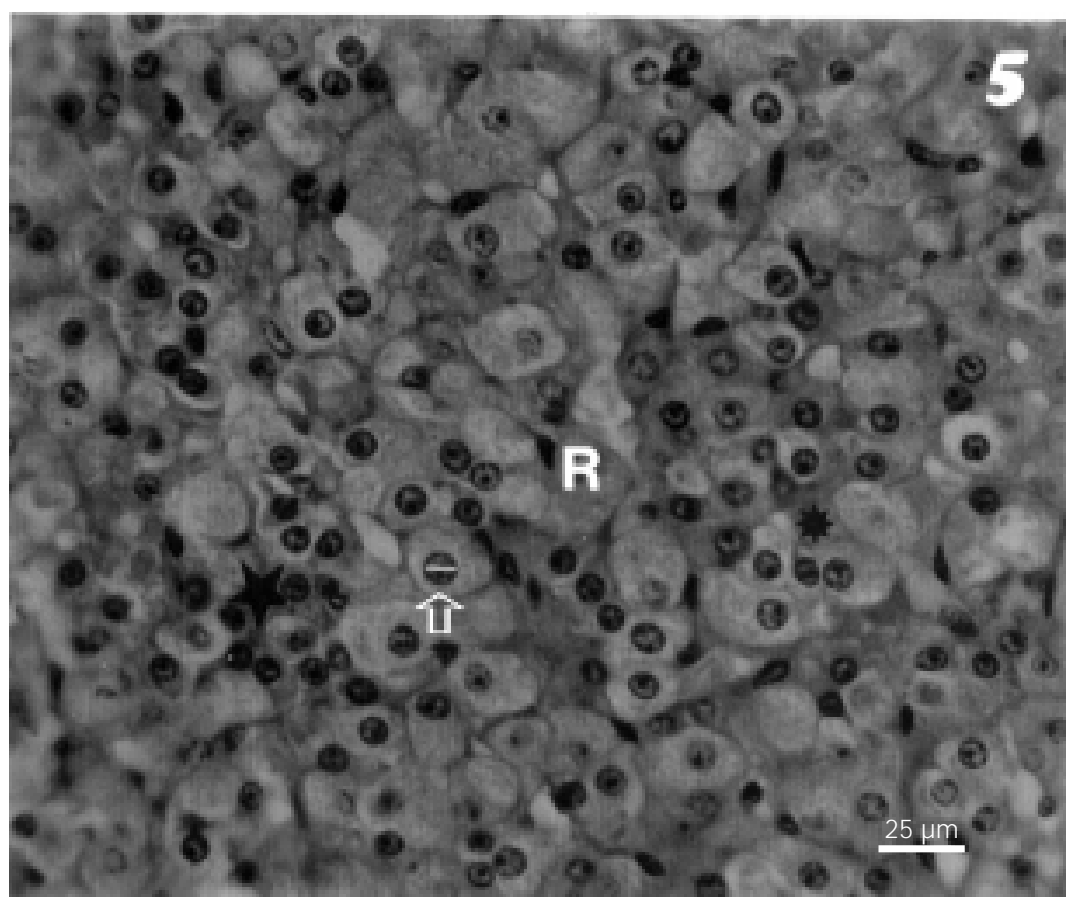

Figure 5 - Reticularis region (R) of a viscacha captured in March (summer). Most of the cells exhibit nuclei with fine chromatin and clear cytoplasms (arrow), and the nuclear diameter (line) of one of these cells is shown in the figure. The other cellular lineage presents nuclear condensation and dark cytoplasms (star). Colloidal material (*). H-E; 400X.

\section{Seasonal morphometric analysis}

\section{Seasonal variation of nuclear diameter in adrenal cortex}

The results obtained by morphometric analysis of the nuclear diameter in three cortex regions are shown in Table 2 . In the glomerulosa, fasciculata and reticular zones the mean values obtained in August were significantly lower than those obtained in March or February (Figures 1, 2, 5 and 6).

\section{Seasonal variation of nuclear volume in adrenal cortex}

The results obtained by morphometric analysis of the nuclear volume in three cortex zones are shown in Table 3. In the glomerulosa, fasciculata and reticular zones the mean values obtained in August were significantly lower than in March or February.

These data show that the nuclear diameter and nuclear volume of the three cortex regions vary with season with the lowest values in August and the highest values between February and March.

\section{Discussion}

Extrinsic factors such as photoperiod (17), water and food availability, temperature and social interactions (18) can mediate neuroendocrine activity. In arid and semiarid environments with wide seasonal light fluctuations and periods of serious hydroid restriction, important changes take place in a number of organs. The neuroendocrine systems which modulate the reproductive and adaptive behavior are the most affected organs. A number of changes in the pineal gland, the pituitary, gonads and adrenal gland have been described, such as a variation in sensitivity to ACTH in the adrenal gland (19).

Serum glucocorticoids and aldosterone 
Figure 6 - Reticularis zone (R) of a viscacha captured in August (winter). The prevailing cells are small, with pycnotic nuclei (arrow), and the nuclear diameter (line) is smaller than that observed in March. H-E; 400X.

increase during the dry season due to hydroid stress and sodium decrease, respectively. In desert environments, water becomes a very important factor that controls processes taking place in the ecosystem (20) due to sporadic and low quantity rainfall.

Seasonal breeding of rodents like male prairie voles (Microtus ochrogaster) is often associated with changes in adrenal function. The adrenal masses are reduced in short-day voles. These changes may reflect seasonal variation in stress responses to annual energetic challenges. Alternatively, the variation in adrenal mass may reflect reproductive activity (21).

Our experimental model, the viscacha, showed seasonal differences in the pinealpituitary-gonadal axis with highest gonad activity in February and lowest gonad activity in August $(15,22)$. The pineal gland, however, had highest activity in winter and lowest at the end of summer (6). The natural photoperiod is the synchronizing signal and the pineal gland, the modulator. Light synchronizes the pineal activity starting from the impact of the light-dark cycle on the photoreceptor organ, the retina. The pineal gland is stimulated in darkness and depressed in light (23). Other parameters such as the diet, the composition of which varies seasonally according to the phenology of plants, have also been studied (24).

In the present study, the relations among photoperiod, water restriction, neuroendocrine activity and adrenal cortex were studied in order to propose a probable mechanism of action. The different cortical regions showed significant seasonal changes. The glomerulo$\mathrm{sa}$, fasciculata and reticular zones exhibited the highest nuclear volumes during the February-March period and the lowest in August. These morphological changes are related to

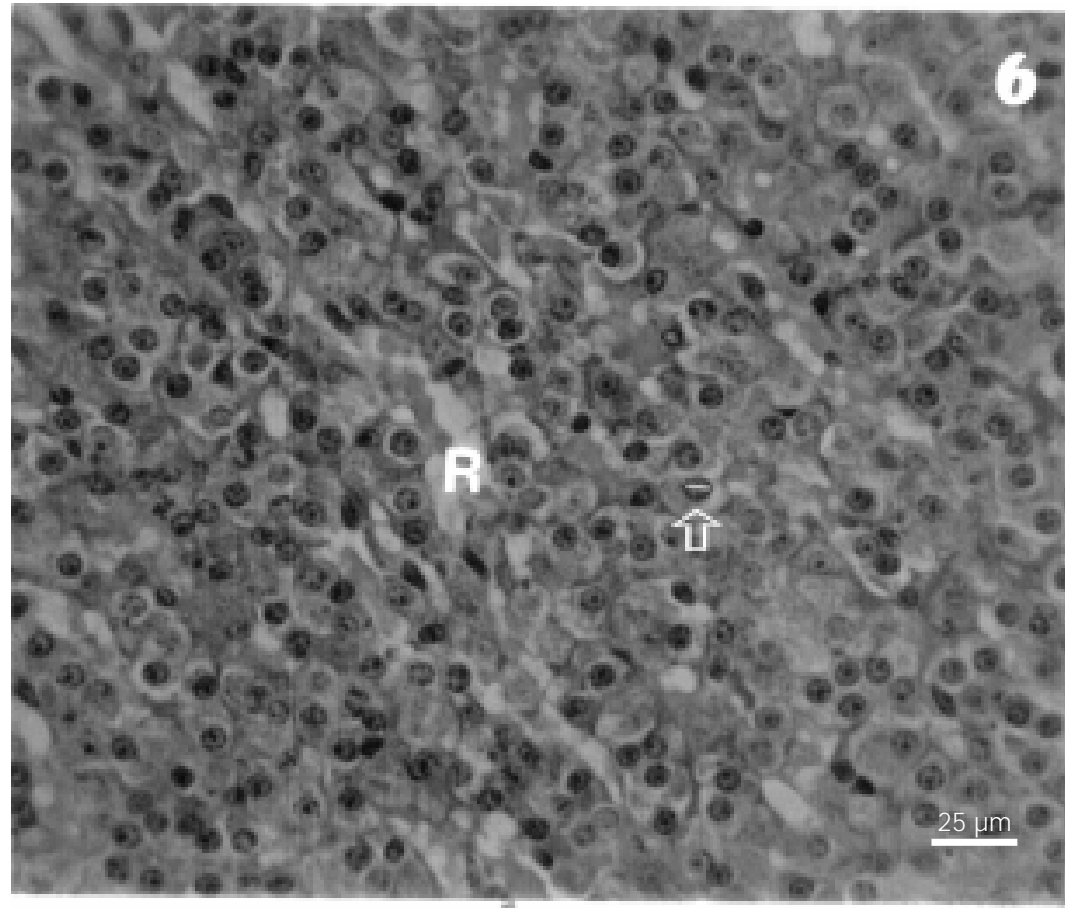

Table 2 - Seasonal variation of nuclear diameter in adrenal cortex of viscacha.

Data are reported as mean $\mu \mathrm{m} \pm \mathrm{SEM} . \mathrm{N}=4$. Superscripts are used to denote statistically significant differences between means $(P<0.01$, Tukey test). Glomerulosa (ANOVA, $\mathrm{P}<0.005$ ), fasciculata (ANOVA, $\mathrm{P}<0.001$ ) and reticularis (ANOVA, $\mathrm{P}<0.005$ ). Data for solar irradiation are expressed as heliophany $(\mathrm{H})$ and are the monthly average.

\begin{tabular}{lcccc}
\hline Month & Glomerulosa & Fasciculata & Reticularis & Heliophany $(\mathrm{H})$ \\
\hline February & $6.034 \pm 0.046^{\mathrm{b}}$ & $8.162 \pm 0.071^{\mathrm{a}}$ & $5.848 \pm 0.15^{\mathrm{b}}$ & 10.56 \\
March & $6.330 \pm 0.053^{\mathrm{a}}$ & $7.465 \pm 0.038^{\mathrm{b}}$ & $6.216 \pm 0.17^{\mathrm{a}}$ & 8.2 \\
May & $5.976 \pm 0.056^{\mathrm{b}}$ & $7.441 \pm 0.041^{\mathrm{b}}$ & $5.069 \pm 0.06^{\mathrm{c}}$ & 6.4 \\
August & $5.498 \pm 0.047^{\mathrm{d}}$ & $6.783 \pm 0.067^{\mathrm{d}}$ & $4.971 \pm 0.19^{\mathrm{d}}$ & 7.04 \\
September & $6.066 \pm 0.050^{\mathrm{b}}$ & $6.784 \pm 0.055^{\mathrm{d}}$ & $5.222 \pm 0.12^{\mathrm{c}}$ & 7.39 \\
November & $6.210 \pm 0.054^{\mathrm{a}}$ & $7.216 \pm 0.057^{\mathrm{c}}$ & $5.192 \pm 0.17^{\mathrm{c}}$ & 10.2
\end{tabular}

Table 3 - Seasonal variation of nuclear volume in adrenal cortex of viscacha.

Data are reported as mean $\mu \mathrm{m}^{3} \pm \mathrm{SEM} . \mathrm{N}=4$. Different superscripts are used to denote statistically significant differences between means $(P<0.05$, Tukey test). Glomerulosa (ANOVA, $\mathrm{P}<0.005$ ), fasciculata (ANOVA, $\mathrm{P}<0.0001$ ) and reticularis (ANOVA, $P<0.0005$ ).

\begin{tabular}{lccc}
\hline Month & Glomerulosa & Fasciculata & Reticularis \\
\hline February & $115 \pm 1.07^{\mathrm{b}}$ & $286.4 \pm 14.72^{\mathrm{a}}$ & $104.8 \pm 3.12^{\mathrm{b}}$ \\
March & $133.1 \pm 7.3^{\mathrm{a}}$ & $218.4 \pm 13.71^{\mathrm{b}}$ & $126.3 \pm 9.49^{\mathrm{a}}$ \\
May & $111.7 \pm 3.0^{\mathrm{b}}$ & $215.5 \pm 5.24^{\mathrm{c}}$ & $67.63 \pm 4.18^{\mathrm{c}}$ \\
August & $88.24 \pm 9.9^{\mathrm{c}}$ & $163.7 \pm 7.78^{\mathrm{d}}$ & $64.58 \pm 4.53^{\mathrm{d}}$ \\
September & $116.5 \pm 7.7^{\mathrm{b}}$ & $165.1 \pm 16.63^{\mathrm{d}}$ & $76.23 \pm 11.83^{\mathrm{c}}$ \\
November & $125.7 \pm 6.5^{\mathrm{a}}$ & $197.1 \pm 11.1^{\mathrm{c}}$ & $74.29 \pm 8.38^{\mathrm{c}}$
\end{tabular}


the secretory activity of the adrenal gland. Probably, this is closely related to the variations that were found in the activity of the pineal gland of this rodent throughout the year (6). Its action on glomerulosa (25), fasciculata (26) and reticularis zones has been described by other authors. In addition, the results of the reproductive study matched those obtained for the inhibitory action of the pineal on both the pituitary-gonadal and the pituitary-adrenal systems.
Although it cannot be denied that hydric stress plays an important role during the winter (dry season), we think that the melatonin effect reverses the stressing stimulatory action produced by the lack of water. The short photoperiod to which the viscacha is subjected during winter could induce a melatonin increase by inhibition of the adrenal cortex, as also observed in terms of the decrease of nuclear volume and cellular activity.

\section{References}

1. Tamarkin L, Baird CJ \& Almeida OF (1985). Melatonin: a coordinating signal for mammalian reproduction? Science, 227: 714-720.

2. ArendtJ (1988). Melatonin. Clinical Endocrinology, 29: 205-229.

3. Clarke J R \& Forsyth IA (1964). Seasonal change in the gonads and accessory reproductive organs of the vole (Microtus agrestis). General and Comparative Endocrinology, 4: 233-242.

4. Lecyk M (1963). Dependence of breeding in the field vole, Microtus anvalis (Pall) on light intensity and wavelength. Zoologist Population, 12: 255-268.

5. Hoffman K (1973). The influence of photoperiod and melatonin on testis size, body weight and pelage colour in the dzungarian hamster (Phodopus Sungorus). J ournal of Comparative Physiology, 85: 267-282.

6. Dominguez S, Piezzi R, Scardapane $L \&$ Guzman J (1987). A light and electron microscopic study of pineal gland of viscacha (Lagostomus maximus maximus). J ournal of Pineal Research, 4: 211-219.

7. Scardapane L (1990). Aspectos histofisiológicos de la pars intermedia hipofisaria de Lagostomus maximus maximus. Doctoral thesis, Biblioteca Central Nacional de San Luis, San Luis, Argentina.

8. Golikov PP (1974). Melatonin action on the rate of aldosterone and corticosterone secretion in intact, pseudoepiphysectomized and epiphysectomized rats. Pharmacology and Toxicology, 37: 696-698.

9. Ottenweller J E, Tapp WN, Pitman DL \& Natelson BH (1987). Adrenal, thyroid and testicular hormone rhythms in male golden hamsters on long and short days. American J ournal of Physiology, 253: 321 328.

10. Kinson GA (1968). Adrenocortical hor- mone secretion at various time intervals after pinealectomy in the rat. General and Comparative Endocrinology, 10: 447-449.

11. Rebuffat $P$, Mazzocchi G, Gottardo G, Coi A, Meneghelli $V \&$ Nussdorfer GG (1987). An ultrastructural morphometric study of the effects of chronic melatonin administration on the zona fasciculata of the rat adrenal cortex. J ournal of Submicroscopic Cytology, 19: 415-421.

12. Krzysztof W, Neri G, Nussdorfer $G \&$ Malendowicz $L$ (1995). Effects of sex hormones on the steroidogenic activity of dispersed adrenocortical cells of the rat adrenal cortex. Pergamon, Life Sciences, 57: 833-837.

13. Piezzi R, Guzman J, Pelzer L, Scardapane L \& Dominguez S (1984). Biological role of pineal response to the environmental photoperiod. Archivo de Biología Médica Experimental, 17: 273-282.

14. Mohamed $F$, Fogal $T$, Dominguez $S$, Scardapane L, Guzman J \& Piezzi R (1994). Seasonal variations and ultrastructure of colloid accumulation in the pituitary pars distalis of viscacha (Lagostomus maximus maximus). Biocell, 18: 23-31.

15. Muñoz $E$, Fogal $T$, Dominguez $S$, Scardapane L, Guzman J \& Piezzi R (1997). Seasonal change of Leydig cells of viscacha (Lagostomus maximus maximus). A light and electron microscopy study. Tissue and Cell, 29: 119-128.

16. Steer W (1981). Understanding to Cell Structure. Cambridge University Press, Cambridge.

17. Reiter RJ (1983). The pineal gland: an intermediary between the environment and the endocrine system. Psychoneuroendocrinology, 8: 31-40.

18. Gets L, Macguire B, Pizzuto T, Hofmann J $\&$ Frase B (1993). Social organization in free living prairie vole (M icrotus ochrogas- ter). J ournal of Mammalogy, 74: 44-58.

19. Amirat $Z \&$ Brudieux R (1993). Seasonal change in in vivo cortisol response to $\mathrm{ACTH}$ and in plasma and pituitary concentrations of ACTH in desert rodents, the sand rat (Psammonys obesus). Comparative Biochemistry and Physiology, 104A: 29-34.

20. Noy-Meir I (1973). Desert ecosystems: environment and producers. Annual Review of Ecology and Systematics, 4: 2551.

21. Nelson R, Fine J, Demas G \& Moffatt C (1996). Photoperiod and population density interact to affect reproductive and immune function in male prairie voles. American Physiological Society, 39: R571R577.

22. Fuentes L, Caravaca N, Pelzer L, Scardapane L \& Guzman J (1991). Seasonal variations in the testis and epididymis of viscacha (Lagostomus maximus maximus). Biology of Reproduction, 45: 493-497.

23. Cardinali D (1986). The pineal gland as multieffector organ. In: Reiter RJ \& Karasek M (Editors), Advances in Pineal Research. Vol. 1. J. Libbey y Co. Ldt., 129-138.

24. Branch L (1994). Diet selection of the plains viscacha (Lagostomus maximus maximus) in relation to resource abundance in semi-arid scrub. Fauna: Viscacha, 30-33.

25. Kinson GA (1967). Effects of the pinealectomy on adrenocortical secretion in normal rats and in rats with experimental renal hypertension. J ournal of Endocrinology, 37: 37-38.

26. Heiman ML (1980). Inhibitory effects of pineal extracts on adrenal cortex. Lack of competition with ACTH. Hormone Research, 12: 104-112. 